\title{
Banking supervision: current trends and prospects
}

\author{
Antipin Dmitriy Alekseevich \\ Department of Economic Theory and Finance, \\ Institute of Economics, Management and Law, \\ Irkutsk National Research Technical University \\ Irkutsk, Russian Federation \\ dmitrii_antipin@mail.ru
}

\author{
Pakholchenko Valentina Mikhailovna \\ Department of Economic Theory and Finance, \\ Institute of Economics, Management and Law, \\ Irkutsk National Research Technical University \\ Irkutsk, Russian Federation \\ $\underline{\text { sarevok@mail.ru }}$
}

\author{
Tauryanskaya Olga Valentinovna \\ Department of Economic Theory and Finance, \\ Institute of Economics, Management and Law, \\ Irkutsk National Research Technical University \\ Irkutsk, Russian Federation \\ ovt58@mail.ru
}

\begin{abstract}
Central banks of all countries realize a function of banking supervision of credit organizations activity. The authors presented a classification of banking supervision organization models according to a degree and a nature criterion of central banks participation in this process. Moreover, the main trends of baking supervision development in Russia are analyzed. The analysis of the main banking supervision models showed that there are specific features of the banking supervision organization established historically and enshrined in national legislation in each country. Based on the results of the main banking supervision organization models research and its development trends, it was concluded that, irrespective of the model chosen for implementing supervisory functions in the financial sector, the role of central banks in this process would remain key for a long time. The paper substantiates the need for regression analysis when selecting indicators. A mathematical model using different combinations of options indicators of the credit institutions' activities. Mathematical models are made and used for three generalized purposes such as for explanation, prediction and management. To increase the efficiency of banking supervision, the work should be continued on further implementation of internationally recognized banking regulation approaches, including the recommendations of the Basel Committee on Banking Supervision. At the same time, the priority is to increase the functioning efficiency of the early response system to the first signs of problems in the activities of credit organizations.
\end{abstract}

Keywords- central bank, banking supervision, banking activity, innovation activity, risk

\section{INTRODUCTION}

Supervising and regulation of banking activities are one of the main conditions and factors of ensuring financial stability. The requirement for the banking supervision institution resulted from the special social importance and responsibility of banks to society.

The problems credited with the successful realization of the innovative projects are very urgent for the Russian Federation, considering the increasing technological degradation of manufacture. Even the most scaled investments in the obsolete technological structures are not capable to bring the proportional return and lead to the costs inflation growth only.

The economic transition of a country towards the innovative way of development is impossible without the formation of a globally competitive, national innovation system. In accordance with the best international practices, the establishment of an effective national innovation system is largely ensured by means of systematic innovation and technological development stimulation in economic sectors, as well as elimination of the fragmentation of the existing innovation system.

Nowadays, the authorities of the federal and regional levels pay considerable attention to the transition of the Russian Federation to the innovative type of economy, what is proved by the development and acceptance of the legislative, program and standard documents complex. The understanding of the municipal management body's importance and value is motivated. The necessary efforts are made for the creation of the municipal management effective system in the Russian Federation.

In Russia, socially focused society formation prospects depend on the efficiency of municipal management structures. Nowadays the strategic character of the problem to put Russia to an innovative way of development is defined in legislative, program and standard documents.

Thereupon the innovative projects mass character will allow Russia to reduce the existing raw materials dependence, to modernize the economy and to create the competitive advantages for the Russian Federation at the international level, which will stimulate the increase of the citizen's living standards and the life quality finally.

Nowadays a modernization and a transition to innovative development of all public life spheres are the key priorities for Russia development. The considerable financial resources are required for the realization of these country priority goals, which provokes the interest to the problems connected with 
the search and the choice of the most suitable sources for the innovative process financial maintenance.

The generally recognized fact is that the economic growth based only on the raw materials export cannot be stable for a long time, and thereupon the financing of the banks innovative activity of special urgency. It is necessary to carry out the transition to an innovative way of development to provide higher and steady rates of the economy growth and to energize the hi-tech manufactures creation.

At the same time, it does not mean raw material extraction shut down as raw materials play an important role both in the Russia's and world economies. National economic development should cater for the accelerated rates of the innovative technologies development.

The crisis of confidence in banking institutions, due to their inability to deliver on their commitments, has the effect of a panic among depositors and as the result of it, there is a disorganization of the monetary sphere and the growth of a social tension. That is why, banks have been traditionally supervised by government agencies.

Various aspects of innovation development were analyzed by A.S. Nechaev [17, 18], R.W.Goldsmith [12], K. Blackburn [2], P.F. Drucker [9], W.H. Janeway [16], R. Atje [1].

Bank financing issues were dealt with by P. Hawkins [15], A.V. Prokopyeva [19], V.R. Bencivenga [3], A. De La Fuente [11].

\section{METHODOLOGY}

Regardless of the chosen model for implementing supervisory functions, the goals and objectives of the banking regulators have not been changed radically with time. The purposes of bank supervision are as follows:

- maintaining the stability of the country's banking system;

- protection of interests of creditors and depositors [9].

The choice of a specific method of organizing and regulation banking supervision is determined by a combination of factors, which diversity gives them a unique national specificity.

\section{RESULTS}

As a rule the innovative activity is characterized by the uncertainty and risk of a high degree and therefore the important principles of its adoption should be the financing sources multiplicity, the flexibility and adaptability to the innovative processes, changing environment, which will promote the fast and effective adoption of the innovations with their further commercialization providing the investments financial return growth.

Development of a financial support system for innovative businesses based on the optimum combination of budgetary and off-budget components is required. And it is necessary to note the importance of mobilization of internal sources for financial support of innovative businesses in Russia.
Currently the government presented by various institutes and the private sector representatives (the pension funds, the insurance companies, the credit organizations), possesses the most powerful financial possibilities which are practically uninvolved in the innovative process but able to strengthen innovative accents when implementing innovation projects and transform innovations into an important factor of the economic growth.

A high risk level of the innovative activity implies that the financial support of the innovative sphere should be preceded on the basis of the financing sources multiplicity. Currently, financial support for innovation businesses includes

- budgetary grants allocated different authority levels,

- special off-budget funds for R\&D activities,

- bank resources, resources of commercial financial organizations (investment companies, commercial banks, insurance companies),

- credit resources of investment banks authorized by the government,

- foreign investment,

- resources of national and foreign research funds,

- savings of individuals.

These financing resources can be attributed to the straight ones. Besides, the banks can practically use indirect financial support for innovation businesses, for example, by means of the tax planning instruments which allow saving the means and giving the chance to finance innovations.

Credit tools as a form of financial support for innovative businesses deserve special attention.

The forms of supervisory functions implementation in each particular country do not remain unchanged, but there are four basic models of the banking supervision organization.

\section{A. The banking supervision organization models}

First, let us analyze some statistics on credit institutions.

TABLE I. INDICATORS OF THE CREDIT INSTITUTIONS IN RUSSIA

\begin{tabular}{|c|c|c|c|c|}
\hline & $\mathbf{2 0 1 2}$ & $\mathbf{2 0 1 3}$ & $\mathbf{2 0 1 4}$ & $\mathbf{2 0 1 5}$ \\
\hline The number of credit institutions & 1094 & 1071 & 1049 & 1021 \\
\hline including: & & & & \\
\hline banks & 1027 & 999 & 976 & 947 \\
\hline other credit organizations & 67 & 72 & 73 & 74 \\
\hline
\end{tabular}

The number of banks has decreased in the Russian Federation.

A comparative analysis of the forms and types of supervision organization of banking activity shows that, despite their diversity, the question of the extent and nature of the involvement of central banks in this process is decisive. 
TABLE II. INDICATORS OF THE CREDIT INSTITUTIONS IN RUSSIA

\begin{tabular}{|c|c|c|c|c|}
\hline & $\mathbf{2 0 1 2}$ & $\mathbf{2 0 1 3}$ & $\mathbf{2 0 1 4}$ & $\mathbf{2 0 1 5}$ \\
\hline $\begin{array}{c}\text { Financial result, } \\
\text { millions of } \\
\text { rubles }\end{array}$ & 1011889 & 993585 & 589141 & 191965 \\
\hline $\begin{array}{c}\text { The volume of } \\
\text { profit, millions } \\
\text { of rubles }\end{array}$ & 1021250 & 1012252 & 853240 & 735803 \\
\hline $\begin{array}{c}\text { The volume of } \\
\text { losses, millions } \\
\text { of rubles }\end{array}$ & 9361 & 18668 & 264098 & 543838 \\
\hline
\end{tabular}

TABLE III. OTHER INDICATORS OF CREDIT INSTITUTIONS

\begin{tabular}{|c|c|c|c|c|}
\hline & $\mathbf{2 0 1 2}$ & $\mathbf{2 0 1 3}$ & $\mathbf{2 0 1 4}$ & $\mathbf{2 0 1 5}$ \\
\hline Assets & 49509647 & 57423070 & 77652994 & 82999708 \\
\hline $\begin{array}{c}\text { Facilities of } \\
\text { the credit }\end{array}$ & 33960085 & 40417733 & 51799476 & 57154529 \\
\hline $\begin{array}{c}\text { Funds of } \\
\text { the budget }\end{array}$ & 40078 & 42090 & 72272 & 66539 \\
\hline $\begin{array}{c}\text { Deposits of } \\
\text { the } \\
\text { individuals }\end{array}$ & 14251046 & 16957531 & 18552682 & 23219077 \\
\hline $\begin{array}{c}\text { Capital of } \\
\text { the credit } \\
\text { institutions }\end{array}$ & 6112937 & 7064349 & 7928438 & 9008553 \\
\hline
\end{tabular}

c. Compiled by the authors

The first model is based on the legislative consolidation of exclusive powers for central banks in the sphere of banking activities supervision and regulation. This model was historically dominant, although not exclusive, since the time of supervisory practice in the field of banking [10].

Not only in many developing countries, but also in countries with a mature market economy, central banks continue to act as a regulator of banking activities. They include Spain, Greece, Portugal and Russia, and with certain reservations - Italy and Holland.

The second model can be called a "mixed model". This model is represented by countries where the functions of supervision and control are carried out by specialized bodies with the direct participation of the central bank and the Ministry of Finance.

The most striking example is the organization of banking supervision in the US, which differs from systems in other countries by a rather complex structure. Unlike other countries in the US, two additional supervisory bodies supervise the savings banks and credit unions: the Office of Thrift Supervision and the National Credit Union Administration. The "mixed model" can be attributed to France, where the central bank of the country - the Bank of France -in a subtle manner plays a leading role in supervising of credit institutions activities.

Among the countries that have adopted the "mixed model" during the transition period, there are Italy and the Netherlands. In this case, there is a division of supervision in two directions, one of which is to ensure the stability of financial institutions; the second one is to ensure the correctness of doing business. As for the Netherlands, the
Bank of the Netherlands is engaged in prudential supervision of all financial institutions, and the Financial Markets Service is the business supervisor. Legislatively, this structure was formalized very recently - by the adoption in early 2005 of the Financial Supervision Law.

The third model is characterized by the fact that supervision of banking activities is carried out by independent specialized bodies in close cooperation with the Ministry of Finance and with more or less expressed mediated participation of the central bank.

Canada, in particular, is among them, which, as Great Britain, is a country where the role of the central bank in regulating and supervising the banking system is very limited. Until recently, these countries included Austria and Germany. But in Germany, the country's central bank, Deutsche Bundesbank, has played and continues to play a more prominent role in regulating banking activities.

The fourth model unites countries that have adopted legislative decisions to create a mega-regulator in the financial services market. In almost all of these countries, supervising functions are separated from central banks. Exceptions are Singapore, where the powers of the mega-regulator are assigned to the central bank, and Ireland, where the megaregulator is created based on an autonomous central bank unit [13].

Banking supervision provides for the development of meaningful (risk-oriented) approaches, including the assessment of the activities of credit institutions and the application of supervisory response measures, based primarily on the content and real assessment of banking risks from the perspective of their potential impact on the stability of credit institutions.

Over the 25-year history of its existence, the organization of supervision and regulation of the activities of commercial Russian banks has gone through a complex stage of development and, in most of the key features, has approached world standards. Increasing the effectiveness of banking supervision is currently being considered as one of the priorities of the Bank of Russia.

In 2015, the Bank of Russia continued to implement internationally recognized approaches to banking regulation, including the recommendations of the Basel Committee on Banking Supervision [5].

In 2015, the Bank of Russia's activities had risk-oriented approaches to supervision and supervisory response. The activity was primarily aimed at applying preventive measures. That information was presented in the Bank of Russia's annual report on the development of the banking sector.

813 credit organizations received recommendations on how to correct the shortcomings identified in their activities. Supervisory meetings on the identified problems and ways of their elimination were held with the representatives of 494 credit organizations.

212 banks were fined, 243 restrictions were imposed on the implementation of certain transactions, including attraction of deposits from the public, 73 credit organizations were 
prohibited from carrying out some banking operations, and 50 - from creating branches. The extreme measure of impact revocation of the license - was applied to 93 credit organizations $[6,7]$.

\section{B. The analysis of the credit institutions' activities}

In order to strengthen the stability of the banking sector, the Bank of Russia will continue supervise policy aimed at removing economically unviable or grossly violating legislation from the market, and, accordingly, creating a threat to the interests of creditors, depositors and banks.

The Bank of Russia will continue the policy of strengthening supervision, while the priority is to increase the effectiveness of the early response system to the first signs of problems in the activities of credit organizations [4].

In addition, in order to improve the effectiveness of banking supervision in the Bank of Russia, it is planned to reorganize supervisory activities. This reorganization is based on the task of separating the risk assessment center from the center for making supervisory decisions by creating a Risk Analysis Service at the level of the central office that will evaluate the assets and operations of credit institutions with the placement of evaluation results in a centralized IT system. Using these estimates, the curator of the credit institution will be able to conduct a systematic analysis of the credit organization's activities, assess its financial position and prepare proposals for measures of impact.

As index selection has the greatest impact on the results of bank activities, we suggest using the correlation and regression analysis to define development trends of the studied phenomena and to reveal the difficult mechanism of the cause and effect interrelations and the dependences between the economic indicators.

Besides, the correlation and regression analysis allows the researchers to reveal by means of supervision both obvious (known) and the implicit (latent) dependences and to express them in the form of the formulas. It gives an opportunity to simulate the phenomena or the processes mathematically.

The practical realization of the correlation and regression analysis includes some basic steps:

- $\quad$ index selection;

- formation of the optimum number of the most essential variable factors which influence a dependent indicator;

- a choice of the communication form which means the regress equation;

- an estimation of the regress function and check of the model adequacy which means the definition of regress parameters numerical values and the calculation of the indicators, characterizing the spent analysis accuracy;

- a comparison of the carried out analysis results with the assumptions formulated in the beginning of the research and the conclusions by the results of the research.
For developing mathematical models, the various variants of index combinations of the credit institutions' activities were used. Some mathematical models are presented below. form:

The linear multiple regression equation has the following

$$
p_{i}=b_{0}+\sum_{j=1}^{n} b_{j} k_{j}+b_{j} m_{j},
$$

where $\quad p_{i}-$ the values of the effective index of the credit institutions' activities;

$b_{0}-$ the free factor;

$b_{j}$ - the model's parameters (regression coefficients);

$k_{j}$ - the factor quantitative indicators of the credit institutions' activities;

$m_{j} \quad$ - the factor quality indicators of the credit institutions' activities (if quality indicators are not used, then $m_{j}=0$ )

$j=\overline{1, n}-$ the number of factors.

Let us analyze the dependence of the income of the credit organization, billion rubles on the volume of loans, billion rubles; foreign exchange transactions, billion rubles; investment business income, billion rubles.

The multiple regression equation takes the following form:

$$
p_{1}=3894.1+2481.4 * k_{1}+529.1 * k_{2}+28.4 * k_{3} \text {, }
$$

where $k_{1}$ - volume of crediting, bln. rub.;

$k_{2}$ - volume of currency transactions, bln. rubles.;

$k_{3}$ - volume of income from operations with securities, bln. rubles.,

$p_{1}$ - volume of income of a credit institution, bln. rubles.

To select the factors to be included in the model, special correlation indices were calculated. Let us develop a correlation matrix (table 4).

TABLE IV. THE SPECIAL FACTORS OF A CORRELATION FOR FORMULA 2

\begin{tabular}{|c|c|c|c|c|}
\hline & $p_{1}$ & $k_{1}$ & $k_{2}$ & $k_{3}$ \\
\hline$p_{1}$ & 1 & & & \\
\hline$k_{1}$ & 0.8 & 1 & & \\
\hline$k_{2}$ & 0.6 & 0.4 & 1 & \\
\hline$k_{3}$ & 0.4 & 0.3 & 0.4 & 1 \\
\hline
\end{tabular}


We get that the greatest impact on spending is provided by the volume of lending.

Let us investigate the dependence of the volume of expenditures on the amount of interests, non-interest expenses, and credit organization operation expenses in billion rubles.

The multiple regression equation takes the following form: $p_{2}=1214.4+524.1 * k_{1}+624.9 * k_{2}+58.2 * k_{3}(3)$

where $\quad k_{1}-$ volume of interest expense, bln. rubles;

$k_{2}$ - volume of expenses for the functioning of a credit institution, bln. rubles;

$k_{3}$ - volume of non-interest expenses, bln. rubles;

$p_{2}-$ volume of expenses of a credit institution, bln. rubles.

We calculate the partial correlation coefficients:

TABLE V. THE SPECIAL FACTORS OF A CORRELATION FOR FORMULA 3

\begin{tabular}{|c|c|c|c|c|}
\hline & $p_{1}$ & $k_{1}$ & $k_{2}$ & $k_{3}$ \\
\hline$p_{1}$ & 1 & & & \\
\hline$k_{1}$ & 0.7 & 1 & & \\
\hline$k_{2}$ & 0.3 & 0.2 & 1 & \\
\hline$k_{3}$ & 0.6 & 0.3 & 0.2 & 1 \\
\hline
\end{tabular}

It is obvious that the volume of expenses is largely influenced by the volume of shipped innovation products and the volume of investments in fixed assets.

The calculation of the abovementioned dynamics factors is a rather effective tool of the bank innovative development management due to its prompt responses and updating in case of changes. The possible negative tendencies of the bank innovative development, which come to light by means of the instruments offered, could be eliminated by means of the financial resources which should be directed to those problem zones which were found out while calculating.

Thus, the achievement of the strategic target connected with Russian economy transition to the innovative way of development is impossible without construction of the debugged system of the innovative activity financial support. Accordingly, the complex application of the abovementioned financial instruments can lead to the considerable economy of bank resources which helps use available forms of financial support for innovative businesses.

\section{DISCUSSION}

For the Russian Federation, the problems connected with the successful innovative projects realization are extremely actual, taking into consideration the increasing technological degradation of the manufacture. Even the scaled investments in the old technological structure cannot bring a proportional return and lead to the growth of a costs inflation only.

Thereupon a mass character of the innovative projects will allow Russia to reduce an existing raw dependence, to modernize the economy and to create the competitive advantages of the Russian Federation in the international market. It will contribute to improving the citizen's life quality level.

The future development of the country should be directed to the accelerated rates of the innovative technologies introduction using incomes from raw materials exportation and increasing raw material processing depth.

We used information from a variety of methods for selecting assessment indicators of banks. We analyzed the indicators used by the various techniques in the estimation of the banks and financing efficiency $[8,13,16]$. Based on the research results and a regression analysis method, we have proposed indicators for full machining capacity assessment banks.

\section{CONCLUSION}

In the world, there are different models for supervising banks and the financial sector, but none of them can be regarded as optimal. Each country chooses a model that suits it economically and politically in accordance with its financial system.

Thus, we used the correlation and regression analysis for the purpose of the most significant indicators selection for the banks. The correlation and regression analysis defines the laws of the studied phenomena development and to understand the difficult mechanism of cause and effect interrelations and dependences between the economic indicators more deeply.

Besides, the correlation and regression analysis allows researchers to reveal by means of supervision not only obvious (known) but also the implicit (latent) dependences and to express them in the form of the formulas or mathematically to simulate the phenomena or processes.

Thus, mathematical models are made and used for three generalized purposes, such as for an explanation, a prediction and a management. Banking financing of innovative-active businesses requires achieving similar purposes, such as the estimations of banks potential, the forecasting and, based on the received results, the definition of the most effective tools for financing the banks innovative activity. The abovementioned facts show that the application of the correlation and regression analysis is quite reasonable.

A number of limitations of the analysis performed have to be mentioned.

First, the use of regression analysis is possible when there is a sufficient number of observations for the study. In practice, it is considered that the number of observations should be not less than 5.6 times the number of factors.

Secondly, the initial set of values should be qualitatively homogeneous. 
Thirdly, the correlation does not give reason to believe that one of the variables causes changes.

Further studies can be directed to the use of indicators to assess the potential of banks. It is necessary to identify the problems in the innovation activities of banks and determining funding to address these issues.

For example, if after the analysis of the potentials revealed that the company has problems in personal potential, it is necessary to develop a program which would be attractive for young professionals to work in the field of innovation.

In addition, further studies may be associated with the development of tools (algorithms, models, methods) to identify promising area.

The global financial crisis has shown that uniform secure banking supervision system has not been worked out yet, the forms of implementation of supervisory powers are changing and improving, and their effectiveness can be assessed only in the conditions of economic or financial upheaval. In this case, the final assessment of the quality of the banking supervision system can be given only after a certain time, taking into account the results of its functioning.

\section{Acknowledgment}

The authors acknowledge receiving support from the statefunded research program of Irkutsk National Research Technical University. We are responsible for all errors as well as the heavy style of the manuscript.

\section{References}

[1] R. Atje, B. Jovanovic, "Stock markets and development", European Economic Review, vol. 37, pp. 632-640, 1993.

[2] K. Blackburn, V.T. Hung, A theory of growth, financial development and trade Economica, vol. 65. GB University of Southampton, 1998, pp. 107-124.

[3] V.R. Bencivenga, B.D. Smith, "Financial intermediation and endogenous growth", Review of Economic Studies, vol. 58 (2), pp. 195209, 1991.
[4] J. Benson Durham, "The effects of stock market development on growth and private investment in lower-income countries", Emerging Markets Review, vol. 3 (3), pp. 211-232, 2008.

[5] K. Blackburn, N.Bose, S.Capasso, "Financial development, financing choice and economic growth", Review of Development Economics, vol. 9 (2), pp. 135-149, 2005.

[6] C. Calderón, L. Liu, "The direction of causality between financial development and economic growth", Journal of Development Economics, vol. 72 (1), pp. 321-334, 2003.

[7] P.J. Dawson, "Financial development and economic growth in developing countries", Progress in Development Studies, vol. 8 (4), pp. 325-331, 2008.

[8] D.W. Diamond, "Financial intermediation and delegated monitoring", Review of Economic Studies, vol. 51 (3), pp. 393-414, 1998.

[9] P.F. Drucker, Innovation and Entrepreneurship. New York: Harper \& Row, 1985, pp. 57-89.

[10] A.B. Fanta, D. Makina, "Equity, bonds, institutional debt and economic growth", South African Journal of Economics, vol. 85, pp. 86-97, 2016.

[11] A. De La Fuente, J.M. Marín, "Innovation, bank monitoring, and endogenous financial development", Journal of Monetary Economics, vol. 38 (2), pp. 269-301, 1994.

[12] R.W.Goldsmith, Financial Structure and Development, New Haven: Yale University Press, 1969, pp. 102-108.

[13] J. De Gregorio, S.-J. Kim, "Credit markets with differences in abilities: Education, distribution, and growth", International Economic Review, vol. 41 (3), pp. 579-607, 1998.

[14] J. Greenwood, B. Jovanovic, "Financial development, growth, and the distribution of income", Journal of Political Economy, vol. 98 (5), pp. 1076-1107, 1990.

[15] P. Hawkins, "South Africa's financial sector ten years on: Performance since democracy", Development Southern Africa, vol. 21 (1), pp. 179204, 2004.

[16] W.H. Janeway, Doing Capitalism in the Innovation Economy: Markets, Speculation and the State. Cambridge University Press, 2012, pp: 217268.

[17] A.S. Nechaev, O.V. Antipina, "Technique of tax rates and customs duties updating as the tool of enterprises innovative activity stimulation", Modern Applied Science, vol. 9 (2), pp: 88-96, 2015.

[18] A.S. Nechaev, O.V. Antipina, A.V. Prokopyeva, "The risks of innovation activities in enterprises", Life Science Journal, vol. 11, pp: 574-575, 2014.

[19] A.V. Prokopyeva, A.S. Nechaev, "Key features of risks of company innovative activities", Middle East Journal of Scientific Research, vol. 17 (2), pp. 233-236, 2013. 